\title{
PREHARVEST CALCIUM SPRAYS WERE NOT ALWAYS NEEDED TO IMPROVE FRUIT QUALITY OF 'GALA' APPLES IN BRAZIL'
}

\author{
PAULO ROBERTO ERNANI², JAQUES DIAS ${ }^{3}$, CASSANDRO VIDAL TALAMINI DO AMARANTE $^{2}$, \\ DIORVÂNIACARDOSORIBEIRO ${ }^{4}$, DOUGLAS ANTONIOROGERI ${ }^{4}$
}

ABSTRACT - Calcium sprays have normally improved both the quality and the storage life of apples throughout the world because $\mathrm{Ca}$ helps to prevent many fruit disorders and that taken up from the soil does not often reach the fruit in adequate amounts. Since the efficacy of Ca sprays varies according to soil, apple cultivar, and weather conditions, this study was carried out from 1998 to 2004, in the Southern of Brazil, in order to assess the effect of Ca sprays on the quality and storability of 'Gala' fruits. The experiment was set up in an orchard planted in 1988, on a density of 1234 trees/ha. Treatments consisted of $0,4,8$, and 12 annual sprays of $0.5 \% \mathrm{CaCl}_{2}$ regularly distributed 30 days after petal fall until one week before harvest. Fruits of the same size and maturity level were annually analyzed at harvest and after five months of conventional cold storage $\left(-1^{\circ} \mathrm{C}\right.$ and $90-95 \%$ of $\left.\mathrm{RH}\right)$. In five out of six seasons, fruits from all treatments were free of any physiological disorder, and Ca sprays had no effect on leaf composition and on any fruit attribute (soluble solids, titratable acidity, starch pattern index, flesh firmness, and concentrations of $\mathrm{N}, \mathrm{K}, \mathrm{Ca}$ and $\mathrm{Mg}$ ). In the season of 2000/ 2001, however, when yield was $18 \mathrm{t} \mathrm{ha}^{-1}$ and fruits had an average weight of $175 \mathrm{~g}$, the incidence of bitter pit plus lenticel blotch pit on stored fruits was $24 \%$ in the treatment with no calcium sprays and it decreased up to $2 \%$ in that with 12 sprays. Two seasons later, yield was also low $\left(25 \mathrm{t} \mathrm{ha}^{-1}\right)$ and fruits were large (168 $\mathrm{g}$ each), but they did not show any physiological disorder regardless of the number of Ca sprays. It seems that the incidence of Ca related disorders in 'Gala' apples grown on limed soils in Brazil with no excess of any nutrient only occurs on seasons with low crop yield, as a result of large fruits and a high leaf/fruit ratio, associated with some unknown environmental conditions.

Index terms: Malus domestica, nutrition, bitter pit, lenticel blotch pit, calcium chloride.

\section{PULVERIZAÇÕES COM CÁLCIO EM PRÉ-COLHEITA NEM SEMPRE MELHORAM A QUALIDADE DE MAÇÃS 'GALA’ NO BRASIL}

RESUMO - Pulverizações com cálcio normalmente melhoram a qualidade e a capacidade de armazenamento de maçãs porque este nutriente ajuda a prevenir muitos distúrbios fisiológicos, associado ao fato de que a absorção de Ca, a partir do solo, às vezes não chega aos frutos em quantidades adequadas. Como a eficiência das pulverizações com Ca varia com o tipo de solo, com a cultivar e com as condições climáticas, conduziu-se o presente trabalho com o objetivo de avaliar o efeito das mesmas na qualidade e na capacidade de armazenamento de maçãs da cultivar Gala. O experimento foi conduzido de 1998 até 2004, em Vacaria-RS, sobre um pomar plantado em 1988, numa densidade de 1.234 árvores por hectare. Os tratamentos consistiram em 0; 4; 8 e 12 pulverizações anuais com solução de $\mathrm{CaCl}_{2}$ 0,5\%, regularmente distribuídas desde 30 dias após a queda de pétalas até uma semana antes da colheita. Frutos de mesmo tamanho e com mesmo nível de maturação foram analisados na colheita e após 5 meses de armazenamento em câmaras frigoríficas convencionais $\left(-1^{\circ} \mathrm{C}\right.$ e $90-95 \%$ UR). Em cinco das seis safras, não houve incidência de distúrbios fisiológicos nos frutos em nenhum tratamento, e as pulverizações com Ca não afetaram a composição química das folhas e nenhum atributo dos frutos (sólidos solúveis, acidez titulável, índice de iodo-amido, firmeza e concentração de N, K, Ca e Mg). Na safra de 2000/2001, entretanto, quando a produtividade foi baixa $\left(18 \mathrm{t} \mathrm{ha}^{-1}\right)$ e os frutos apresentavam um peso médio de $175 \mathrm{~g}$, a incidência de "bitter pit" e a depressão lenticelar atingiram $24 \%$ das maçãs que não foram pulverizadas com Ca, tendo diminuído para $2 \%$ nas que receberam 12 pulverizações. Dois anos mais tarde, a produtividade foi novamente baixa $\left(25 \mathrm{t} \mathrm{ha}^{-1}\right)$, e os frutos foram grandes $(168 \mathrm{~g})$, mas não houve incidência de nenhum distúrbio fisiológico, independentemente do número de pulverizações com Ca. Verifica-se, portanto, que o aparecimento de distúrbios fisiológicos em maçãs 'Gala', produzidas em pomares da região Sul do Brasil com acidez adequadamente corrigida e sem excesso de nutrientes, somente ocorre em áreas com baixa produtividade, em função da existência de frutos grandes e da alta relação entre folhas e frutos, associada com alguns fatores climáticos predisponentes ainda desconhecidos.

Termos para indexação: Malus domestica, nutrição, "bitter pit", depressão lenticelar, cloreto de cálcio.

${ }^{1}$ (Trabalho 249-07). Recebido em: 19-10-2007. Aceito para publicação em: 09-09-2008.

${ }^{2}$ Eng $^{\circ}$. Agr ${ }^{\circ}$., Ph.D., Professor da Universidade do Estado de Santa Catarina (UDESC), Pesquisador do (CNPq). Caixa Postal 281, Lages-SC, Brasil. E-mail: prernani@cav.udesc.br; amarante@cav.udesc.br

${ }^{3}$ Eng $^{\circ}$. Agr ${ }^{\circ}$., Agropecuária Schio Ltda., Vacaria-RS.

${ }^{4}$ Eng $^{\mathrm{o}}$. Agr ${ }^{\circ}$., Estudante de do Curso de Mestrado em Agronomia da UDESC.

Rev. Bras. Frutic., Jaboticabal - SP, v. 30, n. 4, p. 892-896, Dezembro 2008 


\section{INTRODUCTION}

Apple fruit quality is a result of many management practices including pollination (Buccheri \& Di Vaio, 2004), pruning (Bound \& Sumners, 2001), thinning, plant nutrition (Telias et al., 2006) and crop load, in addition to soil type and weather conditions. In terms of nutrition, calcium is the nutrient with the highest effect on the storage potential and quality of apples because it helps to maintain membrane stability and is an integral part or the cell wall. When the level of $\mathrm{Ca}$ in the fruits is below normal, they are susceptible to many disorders, including internal breakdown, bitter pit and lenticel blotch pit (Ferguson \& Watkins, 1989; Hewett and Watkins, 1991), resulting in reduced fruit shelf life and marketability. Calcium also has direct influence on ripening attributes such as respiration, ethylene production, and flesh firmness (Beavers et al., 1994; Siddiqui \& Bangerth, 1995; Gerasopoulos \& Richardson, 1999; Fallahi et al., 2002).

The content of $\mathrm{Ca}$ in the fruit depends on both Ca uptake from the soil and its translocation within the plant through the fruit. The amount of Ca taken up by plant roots is directly related to $\mathrm{Ca}$ available in the soil and to the soil volumetric water since this nutrient moves toward roots essentially by mass flow (Barber, 1995). Therefore, high levels of some cations such as $\mathrm{K}^{+}, \mathrm{NH}_{4}^{+}$, and $\mathrm{Mg}^{+2}$ may depress Ca uptake (Neilsen \& Neilsen, 2006) because they compete for the adsorbing sites in the root membranes. Translocation of calcium to the fruit is affected by the atmospheric water vapor partial pressure and by the ratio of leaf to fruit, in addition to the fruit size (Raese, 1989; Ferguson \& Watkins, 1989). Since Ca is mainly supplied in the plant through the xylem, most $\mathrm{Ca}$ that reaches the fruit must be taken up from the soil in the early part of the fruit development, within the first two months after full bloom.

Increasing $\mathrm{Ca}$ content in apple fruits is a permanent concern of agronomists and growers. When Ca uptake from the soil is not sufficient to promote a desirable level in the fruits, sprays of Ca compounds is a supplemental strategy to improve its concentration in the fruit (Johnson \& Dover, 2002) and thus fruit quality and storability (Van Goor, 1971; Hewett \& Watkins, 1991; Siddiqui \& Bangerth, 1995). Sprays of Ca normally prevent most physiological disorders (Neilsen \& Neilsen, 2002; Yuri et al., 2002; Lötze \& Theron, 2006), but the degree of success varies according to natural predisposition to the symptoms, growing season, cultivar, and environmental conditions. The increase of calcium in the fruits resulting from Ca sprays, however, is normally low (Neilsen \& Neilsen, 2002) or even inexistent.

In Brazil, apple production began around 1970, but research studies dealing with nutrition are still incipient. Few studies were conducted to assess the effect of $\mathrm{Ca}$ on apple quality. In addition, Brazilian soils are naturally very acid and have predominantly variable charge into which many reactions that affect plant nutrient availability are quite different from soils carrying predominantly permanent charge. Since all factors related to Ca uptake widely vary among soils and environmental conditions, as well as across seasons, the requirement of supplemental $\mathrm{Ca}$ through orchard sprays must be locally evaluated.

This study was carried out to evaluate the effect of the number of calcium sprays on fruit quality and storability of ' $G a l a$ ' apples in a long-term experiment in Southern Brazil.

\section{MATERIALS AND METHODS}

This study was carried out from 1998 to 2004, in Vacaria, in the State of Rio Grande do Sul, Southern Brazil. The experiment was set up in a commercial orchard of 'Gala' apples, grafted on M.7 rootstock, planted in 1989 at a density of 1234 trees ha $^{-1}$ (4.5 $\mathrm{x} 1.8 \mathrm{~m}$ ), and trained to a central leader. Before planting, the soil (Humic Hapludox) plow layer was limed and fertilized. Soil samples collected in 1998, from the layer of 0 to $20 \mathrm{~cm}$ depth, showed a pH of $6.8,4.0 \%$ of organic matter, $56 \%$ of clay, $10 \mathrm{mg}$ of $\mathrm{P} \mathrm{kg}^{-1}$, and respectively $0.5,8.0$ and $12 \mathrm{cmol}_{\mathrm{c}} \mathrm{kg}^{-1}$ for exchangeable $\mathrm{K}, \mathrm{Mg}$ and $\mathrm{Ca}$.

Treatments consisted of $0,4,8$ and 12 annual sprayings of $0.5 \% \mathrm{CaCl}_{2}$, adjusted to a volume of nearly $1200 \mathrm{~L} \mathrm{ha}^{-1}$. They were uniformly distributed along the season, beginning 30 days after petal fall and finishing one week before fruit harvest. Each experimental unit consisted of six trees distributed along the row, but only the central four plants were used for determinations. Each treatment was applied to five parallel rows and the trees used for evaluations were located in the central row. The four replicates were arranged in a randomized complete block design.

The experimental area received all management practices used in the commercial orchard, including bud break (mineral oil + hydrogen cyanamide), application of herbicide (glyphosate), insecticides and fungicides, winter and summer pruning, and hand thinning. Since the ground cover management system may affect nutrient availability, a 2.0-meter-wide killed sod strip was maintained in the tree row.

Two-hundred-twenty fruits of uniform size and maturity level were randomly collected per plot at the harvest time. Twenty fruits were used for measurements of mineral nutrient concentration and quality attributes at harvest. The remaining 200 fruits were stored in a conventional cold storage at $-1^{\circ} \mathrm{C}$ and $90-95 \%$ of relative humidity $(\mathrm{RH})$ for five months prior to determination of fruit quality attributes and storage disorders. Fruits were analyzed for total soluble solids (TSS; ${ }^{\circ}$ Brix), titratable acidity (TEA; meq of malic acid $100 \mathrm{~mL}^{-1}$ ), starch pattern index (scale of 1 to 5, where 1 indicates the least and 5 the most starch to sugar conversion), flesh firmness $(\mathrm{N})$, skin background color (scale of 1 to 8, corresponding to dark-green and yellow-green, respectively), severity of russeting $\left(\mathrm{cm}^{2}\right.$ fruit $\left.{ }^{-1}\right)$, incidence $(\%)$ of bitter pit and lenticels blotch pit, and concentration of N, K, Ca and $\mathrm{Mg}$. Attributes related to fruit quality were determined according to the methodology described by Amarante et al. (2002). Since it was not expected any increase of Ca sprays on crop load, both fruit yield and fruit weight were determined for the entire experimental area. Samples of 40 leaves were collected in each plot approximately 115 days after full bloom and analyzed for $\mathrm{N}, \mathrm{K}, \mathrm{Ca}$ and $\mathrm{Mg}$.

In order to assess the fruit mineral composition, two longitudinal slices were obtained from each fruit, including the 
peel. These parts were blended, and approximately $5.0 \mathrm{~g}$ of the slurry were wetly digested. Leaf and fruit tissues were digested at $350^{\circ} \mathrm{C}$ with sulfuric acid $\left(\mathrm{H}_{2} \mathrm{SO}_{4}\right)$ plus hydrogen peroxide $\left(\mathrm{H}_{2} \mathrm{O}_{2}\right)$, according to Adler \& Wilcox (1985). Potassium was determined by flame emission spectroscopy, $\mathrm{N}$ by steam distillation in a semi-micro Kjeldahl equipment, and $\mathrm{Ca}$ and $\mathrm{Mg}$ by inductively coupled plasma (ICP) spectroscopy.

The interaction of $\mathrm{Ca}$ treatments and growing seasons for each attribute was evaluated by ANOVA, and the statistical significance of the effect of the number of $\mathrm{Ca}$ sprays was evaluated by regression analysis.

\section{RESULTS AND DISCUSSION}

Average fruit yield and fruit weight of entire experimental area varied across seasons (Table 1). Crop load was moderate to high in four out of six production seasons, with productivities ranging from 48 to $82 \mathrm{t} \mathrm{ha}^{-1}$. In the other two years (2000-01 and 2002-03), crop load was low with fruit yield of 18 and $25 \mathrm{tha}^{-1}$, respectively. The average fruit weight across treatments considering all experimental period varied from 100 to $175 \mathrm{~g}$, and it was inversely related to yield [fruit weight $(\mathrm{g})=192-1.05 \mathrm{tha}^{-1}$; $\left.r^{2}=0.96\right]$ showing that each increase in one ton of fruits per hectare would decrease fruit weight in $1.0 \mathrm{~g}$. Since fruit yield was positively related to the number of fruits per tree within each year, the ratio of leaf to fruit decreased with increases on crop load.

Spraying the trees with $0.5 \%$ of calcium chloride solution had no effect on most postharvest attributes. All attributes used to evaluate fruit quality, determined at harvest (Table 2) or after five months of storage (data not shown), were not influenced by the $\mathrm{Ca}$ treatments regardless of number of sprays or growing season. In addition, there was no interaction between the number of $\mathrm{Ca}$ sprays and growing season. Thus, the results of these attributes (averaged across years) were within the normal range. The severity of russeting was small, only $4.6 \mathrm{~cm}^{2}$ fruit ${ }^{-1}$. Mean values for flesh firmness, TSS, starch pattern index, and TEA, after harvest, were, respectively, $75 \mathrm{~N}, 11.8^{\circ} \mathrm{Brix}, 4.4$ (in a range of 1 to 5 ) and 5.0 meq of malic acid $100 \mathrm{~mL}^{-1}$. After five months of storage, fruit firmness dropped to $51.6 \mathrm{~N}$ and SSC increased to $12.8^{\circ}$ Brix. Beavers et al. (1994) pressure infiltrated fruits of some apple cultivars using different Ca sources and obtained increases on firmness that was positively correlated with increases on $\mathrm{Ca}$ content in fruits, which differ from our findings. Yuri et al. (2002) applied different Ca sources in a 'Braeburn' orchard in Chile and found no effect of sprays on weight, seed number, color, and TSS of fruits.

The number of Ca sprays did not affect the mineral composition of the fruit flesh, even for Ca (Table 3). The concentration of these nutrients was not either affected by the growing season. Averaged across years and $\mathrm{Ca}$ treatments, the concentrations of $\mathrm{Ca}, \mathrm{Mg}, \mathrm{K}$ and $\mathrm{N}$ were 41, 49, 744 and $247 \mathrm{mg}$ $\mathrm{kg}^{-1}$, respectively. The concentration of Ca did not differ among the number of $\mathrm{Ca}$ sprays because it was quantified including flesh and skin, and most of $\mathrm{Ca}$ applied via sprays stays just below the peel. In some studies, however, $\mathrm{Ca}$ concentration in the fruits increased with preharvest Ca sprays (Le Grange et al., 1998; Gerasopoulos and Richardson, 1999; Roy et al., 1999), especially when late applied (Johnson \& Dover, 2002) or when Ca was postharvest pressure infiltrated (Beavers et al., 1994; Roy et al., 1999). Neilsen \& Neilsen (2002) evaluated the effect of postbloom calcium chloride sprays on apple cultivars ('Gala', 'Fuji', 'Jonagold') grown on the semi-arid region of British Columbia, Canada, and found no effect or small increases on fruit $\mathrm{Ca}$, depending on year, cultivar, and number of sprays. In addition, they observed that late $\mathrm{Ca}$ sprays were more effective to increase the concentration of fruit $\mathrm{Ca}$ than early sprays. Yuri et al. (2002) found that subepidermal Ca levels in fruits at harvest explained only $53 \%$ of variability in external bitter pit incidence after four months of cold storage. For N, P, and K, Le Grange et al. (1998) also did not find any effect of Ca sprays on apples fruits produced from a four-year-old 'Braeburn' orchard in South Africa.

The influence of the number of Ca sprays on the incidence of fruit disorders varied among seasons. In five out of six production seasons, calcium chloride sprays had no effect on any disorder, and fruits were completely free of them regardless of number of sprays (data not presented). In the 2000-01 growing season, however, incidence of bitter pit and lenticels blotch pit was inversely related to the number of Ca sprays (Figure 1). In the treatment without $\mathrm{Ca}$ sprays, the percentage of fruits containing at least one of these Ca related disorder was $24 \%$ after storage, while in the treatment with the highest number of Ca sprays (twelve), the number of affected fruits reduced to $2 \%$. The concentration of $\mathrm{Ca}$ in the fruit flesh, however, was not affected by number of $\mathrm{Ca}$ sprays, even in this season, probably because the increase of $\mathrm{Ca}$ in the fruits caused by $\mathrm{Ca}$ sprays is normally small (Neilsen \& Neilsen, 2002) and did not attain the significance level. In addition, most Ca taken up from sprays remains near or just beneath the peel, which becomes diluted when flesh and peel are determined together.

Neilsen \& Neilsen (2002) found that Ca sprays completely eliminated the occurrence of bitter pit in 'Braeburn', a cultivar recognized as sensitive to this disorder. In Chile, Yuri et al. (2002) observed that control of internal and external occurrence of bitter pit in 'Braeburn' fruits by $\mathrm{Ca}$ sprays reached $92 \%$ and $82 \%$, respectively. In South Africa, at least 12 sprays of $\mathrm{Ca}$ are recommended for this cultivar (Le Grange et al., 1998). In our study, the incidence of $\mathrm{Ca}$ related fruit disorders was associated with fruit yield because they only occurred in the season 200001, when crop load was low $\left(18 \mathrm{t} \mathrm{ha}^{-1}\right)$, resulting in large fruits (average fruit weight of $175 \mathrm{~g}$ ) and a high leaf/fruit ratio. Large fruits are more susceptible to physiological disorders due to dilution of $\mathrm{Ca}$. A high leaf/fruit ratio also favors the incidence of disorders because leaves effectively compete with fruits for $\mathrm{Ca}$ taken up from the soil. In the other season that carried low crop load (2002-03), fruits from all treatments were free of storage disorder, showing that some environmental factors also influences the incidence of these disorders. Thus, in order to guarantee good fruit quality, at least ten Ca sprays should be applied in orchards of 'Gala' carrying low crop load. 
TABLE 1 - Average fruit yield and fruit weight of the experimental area during the production seasons.

\begin{tabular}{ccc}
\hline Season & Yield $\left(\mathrm{t} \mathrm{ha}^{-1}\right)$ & Mean fruit weight $(\mathrm{g})$ \\
\hline $98 / 99$ & 48 & 135 \\
$99 / 00$ & 80 & 100 \\
$00 / 01$ & 18 & 175 \\
$01 / 02$ & 80 & 112 \\
$02 / 03$ & 25 & 168 \\
$03 / 04$ & 82 & 113 \\
Average & 55.5 & 134 \\
\hline
\end{tabular}

TABLE 2 - Some fruit attributes of 'Gala' apples as affected by the number of preharvest $0.5 \%$ calcium chloride sprays. Values are average of four replications and six growing seasons.

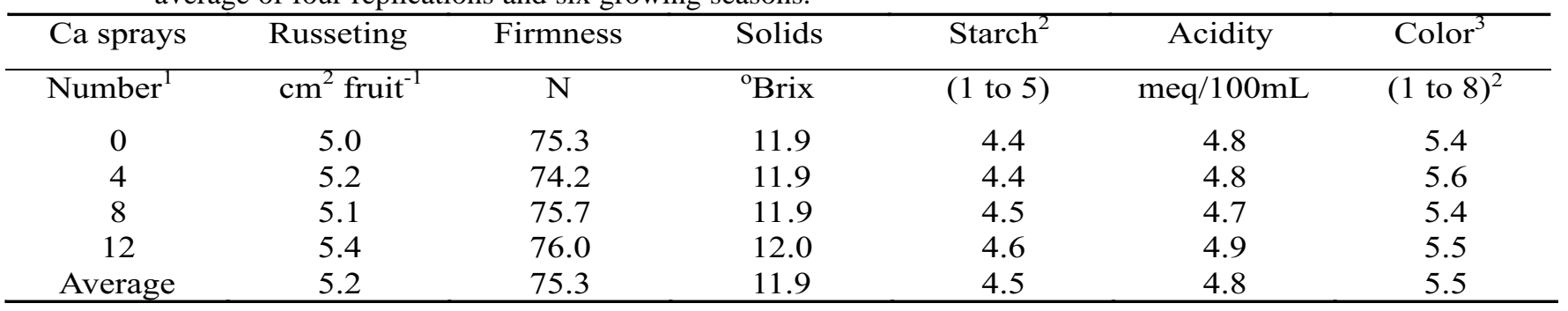

${ }^{1}$ There was no significance $(\mathrm{P}<0.05)$ for the regression coefficients between Ca treatments and any attribute regardless of growing season. ${ }^{2} \mathrm{On}$ a scale of 1 to 5 , where 1 indicates the least and 5 the most starch to sugar conversion.

${ }^{3}$ On a scale of 1 (dark-green) to 8 (yellow-green).

TABLE 3 - Chemical composition of the 'Gala' apple flesh, at harvest, as affected by the number of preharvest $0.5 \%$ calcium chloride sprays. Values are average of four replications and four growing seasons.

\begin{tabular}{|c|c|c|c|c|}
\hline Ca sprays & $\mathrm{N}$ & $\mathrm{K}$ & $\mathrm{Ca}$ & $\mathrm{Mg}$ \\
\hline Number & ------ & ----- & --- & ------. \\
\hline 0 & 277 & 764 & 44 & 53 \\
\hline 4 & 307 & 796 & 43 & 50 \\
\hline 8 & 297 & 788 & 43 & 50 \\
\hline 12 & 277 & 825 & 44 & 51 \\
\hline Average & 290 & 793 & 44 & 51 \\
\hline
\end{tabular}

There was no significance $(\mathrm{P}<0.05)$ for the regression coefficients between Ca treatments and any nutrient regardless of growing season.

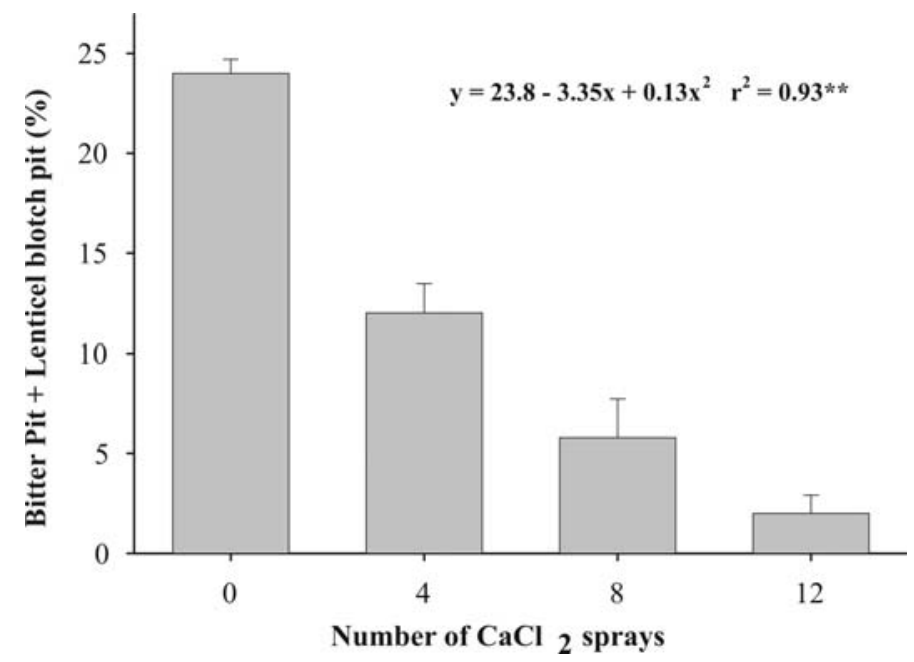

FIGURE 1 - Percentage of bitter pit plus lenticel blotch pit on 'Gala' fruits from 12-years old trees in the 2000/01 growing season following treatment with increasing number Of $0.5 \%$ calcium chloride sprays. Fruit were assessed after five months of cold storage. Average of 4 replications. Line bars indicate standard errors of means. 


\section{CONCLUSION}

Application of calcium chloride sprays to 'Gala' apple trees that were 10 to 12 -year-old had no effect on fruit nutrition and postharvest attributes related to fruit quality regardless of spraying number and growing season. The incidence of $\mathrm{Ca}$ related fruit disorders, however, was not observed on years with high crop load, but appeared in one out of two years with a low crop load and was inversely related to the number of sprays. Thus, when large fruits and a high leaf/fruit ratio are expected to occur, Ca sprays should be applied to ensure good quality of 'Gala' fruits.

\section{AKNOWLEDGEMENTS}

We are thankful to $\mathrm{CNPq}$, a Brazilian research agency, for providing a scholarship for the first and the third authors.

\section{REFERENCES}

ADLER, P.R.; WILCOX, G.E. Rapid perchloric acid digest methods for analysis of major elements in plant tissue. Communications in Soil Science and Plant Analysis, New York,v.16, n.11, p.1153$1163,1985$.

AMARANTE, C.V.T. do; SIMIONI, A.; MEGGUER, C.A.; BLUM, L.E.B. Effect of aminoethoxyvinilglycine (AVG) on preharvest fruit drop and maturity of apples. Revista Brasileira de Fruticultura, Jaboticabal, v.24, n.3, p.661-664, 2002.

BARBER, S.A. Soil nutrient bioavailability: a mechanistic approach. New York: John Wiley \& Sons, 1995. 414p.

BEAVERS, W.B.; SAMS, C.E.; CONWAY, W.S.; BROWN, G.A. Calcium source affects calcium content, firmness, and degree of injury of apples during storage. HortScience, Alexandria, v.29, n.12, p.1520-1523, 1994 .

BOUND, S.A.; SUMMERS, C.R. The effect of pruning level and timing on fruit quality in red 'Fuji' apple. Acta Horticulturae, Wageningen, v.557, p.295-302, 2001.

BUCCHERI, M.; DI VAIO, C. Relationship among seed number, quality, and calcium content in apple fruits. Journal of Plant Nutrition, Monticello, v.27, n.10, p.1735-1746, 2004.

FALLAHI, E.; FALLAHI, B.; RETAMALES, J.B; VALDÉS, C.; TABATABAEI, S.J. Prediction of apple fruit quality using preharvest mineral nutrients. Acta Horticulturae, Wageningen, v.594, p.427-433, 2002.

FERGUSON, I.B.; WATKINS, C.B. Bitter pit in apple fruit. Horticultural Reviews, New York, v.11, p.289-355, 1989.
GERASOPOULOS, D.; RICHARDSON, D.G. Storage temperature and fruit calcium alter the sequence of ripening events of 'd'Anjou' pears. HortScience, Alexandria, v.34, n.2, p.316-318, 1999.

HEWETT, E.W.; WATKINS, C.B. Bitter pit control by sprays and vacuum infiltration of calcium in "Cox"s Orange Pippin" apples. HortScience, Alexandria, v.26, p.284-286,1991.

JOHNSON, D.S.; DOVER, C.J. The effect of calcium and zinc sprays on the texture of 'Cox's Orange Pippin' apples in controlled atmosphere storage. Acta Horticulturae, Wageningen, v.594, p.427-433, 2002.

LE GRANGE, S.A.; THERON, K.I.; JACOBS, G. Influence of the number of calcium sprays on the distribution of fruit mineral concentration in an apple orchard. Journal of Horticultural Science \& Biotechnology, Asford, v.73, n.4, p.569-573, 1998.

LÖTZE, E.; THERON, K.I. Dynamics of calcium uptake with preharvest sprays to reduce bitter pit in 'golden delicious'. Acta Horticulturae, Wageninge, v.721, p. 313-320, 2006.

NEILSEN, G.H.; NEILSEN, D. Effect of foliar zinc, form and timing of Ca sprays on fruit $\mathrm{Ca}$ concentration in new apple cultivars. Acta Horticulturae, Wageningen, v.594, p.435-443, 2002.

NEILSEN, G.H.; NEILSEN, D. The effect of K-fertilization on apple fruit $\mathrm{Ca}$ concentration and quality. Acta Horticulturae, Wageningen, v.721, p.177-184, 2006.

ROY, S.; CONWAY, S.S.; WATADA, A.E.; SAMS, C.E.; ERBE, E.F.; WERGIN, W.P. Changes in the ultrastructure of the epicuticular wax and postharvest calcium uptake in apples. HortScience, Alexandria, v.34, n.1, p.121-124, 1999.

RAESE, J.T. Important considerations about calcium on apples and pears. Good Fruit Grower, Yakima, v.40, p.27-35, 1989.

SIDDIQUI, S.; BANGERTH, F. Effect of pre-harvest application of calcium on flesh firmness and cell-wall composition of applesinfluence of fruit size. Journal of Horticultural Science, Ashford, v.70, p.263-269, 1995.

TELIAS, A.; HOOVER, E.; ROSEN, C.; BEDFORD, D.; COOK, D. The effect of calcium sprays and fruit thinning on bitter pit incidence and calcium content in 'Honeycrisp' apple. Journal of Plant Nutrition, New York, v.29, p.1941-1957, 2006.

VAN GOOR, B.J. The effect of frequent spraying with calcium nitrate solutions on mineral composition and the occurrence of bitter pit of the apple 'Cox's Orange Pippin'. Journal of Horticultural Science, Asford, v.46, p.347-367, 1971.

YURI, J.A.; RETAMALES, J.B.; MOGGIA, C.; VÁSQUES, J.L. Bitter pit control in apples cv. Braeburn through foliar sprays of different calcium sources. Acta Horticulturae, Wageningen, v.594, p.453-460, 2002. 